\title{
STRATEGIES OF DISTRIBUTION EFFECTIVENESS OF SPECIAL PHYSICAL ALLOCATION FUNDS IN THE FIELD OF MARINE AND FISHERIES
}

\author{
Sharah Gita Kalila Lubis*)1, Muhammad Firdaus**), and Tb. Nur Ahmad Maulana***) \\ *) Ministry of National Planning and Development \\ Taman Suropati St. Number 2, Menteng, Jakarta 10310 \\ **) Department of Economics, Faculty of Economics and Management, Bogor Agricultural University \\ Agatis Street, IPB Darmaga Campus, Bogor 16680 \\ ${ }^{* * *}$ School of Business, Bogor Agricultural University \\ Raya Pajajaran Street, Bogor 16151
}

\begin{abstract}
Indonesia still has tremendous opportunities to utilize and develop the potential of fisheries optimally. The government through DAK Marine and Fisheries Sector helps fund the physical development activities in the field of marine and fisheries to support fishery production. The effectiveness of DAK disbursement from the government to various regions becomes very important to accelerate the process of marine and fisheries development. The purposes of this research are as follows: (1) analyzing the constraints of DAK Marine and Fisheries Sector distribution; (2) analyzing the impact of DAK Marine and Fisheries Sector distribution; and (3) formulating the strategies needed to improve the effectiveness of DAK Marine and Fisheries Sector distribution. The processing techniques and data analysis in this research included data panel data regression analysis with Fixed Effect Model (FEM) method using Eviews 8 software and analysis of strategy formulation using Strengths - Weakness - Opportunities - Threats (SWOT) matrix. Based on the results of Regression, DAK Fishing Capture variables have no significant effects on Capture Fishery Production, while DAK Fishery Aquaculture variables have significant effects on Aquaculture Production. The results of formulation of alternative strategies using SWOT matrix exhibit the position point of IFE and EFE score points at the quadrant position III (Turn Around). The recommended strategy is the WO strategy i.e. to minimize the weaknesses to take advantages of opportunities.
\end{abstract}

Keywords: DAK KP, effectiveness, FEM, SWOT Matrix, WO strategy

\begin{abstract}
Abstrak: Indonesia masih memiliki peluang yang sangat besar untuk memanfaatkan dan mengembangkan potensi perikanan secara optimal. Pemerintah melalui DAK bidang Kelautan dan Perikanan membantu mendanai kegiatan pembangunan fisik di bidang kelautan dan perikanan untuk mendukung produksi perikanan. Efektivitas penyaluran DAK Kelautan dan Perikanan dari pemerintah ke berbagai daerah menjadi sangat penting untuk mempercepat proses pembangunan kelautan dan perikanan. Tujuan dari penelitian ini adalah sebagai berikut: (1) Menganalisis kendala penyaluran DAK Kelautan dan Perikanan, (2) Menganalisis dampak penyaluran DAK Kelautan dan Perikanan, dan (3) Memformulasikan strategi yang dibutuhkan untuk meningkatkan efektivitas penyaluran DAK Kelautan dan Perikanan. Teknik pengolahan dan analisis data pada penelitian ini adalah analisis data regresi data panel dengan metode Fixed Effect Model (FEM) menggunakan software Eviews 8 dan analisis perumusan strategi menggunakan matriks Strengths - Weakness Opportunities - Threats (SWOT). Berdasarkan hasil regresi data panel, variabel DAK KP tidak berpengaruh signifikan terhadap produksi perikanan tangkap, namun berpengaruh signifikan terhadap produksi perikanan budidaya. Hasil analisis perumusan strategi bersaing dengan matriks Strengths - Weakness - Opportunities - Threats (SWOT) menunjukkan bahwa pemerintah daerah berada pada kuadran ke III (Run Around Strategy). Strategi yang direkomendasikan adalah strategi WO, yaitu meminimalkan kelemahan untuk memanfaatkan peluang.
\end{abstract}

Kata kunci: DAK KP, Efektivitas, FEM, Matriks SWOT, Strategi WO

\footnotetext{
${ }^{1}$ Corresponding author:

Email: sharahgita@gmail.com
} 


\section{INTRODUCTION}

Indonesia has the potential of marine and fishery resources that can be a source of livelihood for its citizens. However, if we look at the contribution of GDP of Business Field per sub-sector incorporated in the sectors of Agriculture, Forestry, and Fisheries, the Fishery Sub-sector still has not contributed maximally. In 2016, The contribution of the GDP Sub-sector of Fisheries to Agriculture, Forestry and Fishery sector was $19.03 \%$. Furthermore, Zebua and Ramli (2013) stated that the economic potential of fisheries resources is estimated at US\$82 billion per year. If converted into rupiah, it reached IDR1,008.6 trillion. The value of economic resource potential in the fishery sector is still far enough with the value of GDP Sub-Sector of Fisheries where in 2016, it amounted to IDR214.5 Trillion, only $21.3 \%$ of the potential value of IDR $1,008.6$ Trillion so that it can be argued that Indonesia still has a great opportunity to utilize and develop its fisheries potential optimally.

Based on the Government Work Plan (RKP) in 2016, the target for marine and fishery product production was 35.41 million tons. However, the realization of marine and fishery product production in 2016 was just 29.58 million tons, so it had not reached the target. When compared to the 2017 with the target of 39.43 million tons, the production of marine and fishery products in 2016 was still around $83.54 \%$. Therefore, in order to support the achievement of the National Medium-Term Development Plan (RPJMN), the central government through the balancing fund is funding the national development as set forth in the RKP. To overcome the problem of regional funding imbalances, the Central Government will transfer the balance funds, one of which consists of the Special Allocation Fund (DAK) (Suhendra et al. 2015). Balancing funds are funds provided by the central government to meet the needs of regional fiscal gaps (Aimon and Putra, 2016). Balancing funds are intended as one way to implement the decentralization process. Fiscal decentralization is defined as a tool or instrument for the realization of efficient and participatory governance (Sari, 2014).

The Central Government through the DAK Marine and Fisheries (DAK KP) helps fund the physical development activities in the field of marine and fisheries. This is to support basic services of regional affairs (provincial and district/city) in accordance with national priorities. Nevertheless, since the DAK KP was budgeted for the period of 2004-2018, there have been many obstacles in the process of fund distribution, both from technical and non-technical aspects. These constraints can lead to ineffectiveness that resulted in hampering development activities so that the utilization of economic resources Fishery Sub-sector is not optimal. This can be proven from the realization value of DAK KP distribution activities which is still unsatisfactory. The financial realization value of DAK KP based on data from the Ministry of Finance in 2016 was $83.14 \%$. As for the year 2017 per 31 October 2017, it amounted to $72.78 \%$.

Based on the decree of the Minister of Internal Affairs Number 690.900-327 of 1996 on Criteria for Assessment and Financial Performance, the determination of the effectiveness level of expenditure budget for the range of $80 \%$ to $90 \%$ included in the criteria is reasonably effective; however, the criteria still have not reached the expectations. The Central Government should determine the activities of the Special Allocation Fund (DAK) included in the balancing funds to assist certain regions with the aim of assisting in funding specific activities of regional affairs and in accordance with national priorities. The distribution of DAK KP is expected to increase the achievement of fisheries indicators listed in the RPJMN document. In reality, since the budgeting of DAK KP, there have been many obstacles in the process of channeling these funds, both from technical and non-technical aspects. These constraints can lead to ineffectiveness resulting in inhibition of development activities so that the utilization of economic resources Fishery Sub-sector is not optimal.

Previously, there were several studies related to the distribution of DAK both provincially and nationally, but there were still a few researches related to DAK that deal specifically with issues for specific fields. Novarianti (2016) in her thesis examined the effects of local revenues, General Allocation Funds, and Special Allocation Funds on Human Development Index with Capital Expenditure as a Mediating Variable in districts/cities in Indonesia in the period of 2010-2013. Bangun (2009) in his thesis examined the effects of Special Allocation Funds, General Allocation Funds, and local revenues on income per capita. Research related to effectiveness is required to determine whether the distribution of funds is in accordance with the purpose. 
The effectiveness of the distribution of DAK KP is one factor supporting the achievement of targets in the RPJMN document. Hudjuala (2017) explains that effectiveness is a key element to achieve the goals or goals that have been determined. Based on the background that has been described, this research will discuss the effectiveness of the DAK KP distribution, especially about the constraints and impacts in the distribution process so that in the future it is expected to formulate the alternative strategies needed for the distribution of DAK KP to be more effective. Therefore, a strategy is still required so that in the future DAK KP realization can reach a better criterion. The effectiveness of the DAK KP distribution is one factor supporting the achievement of targets in the RPJMN document so that the effectiveness of DAK disbursement from the government to various regions becomes very important to accelerate the process of marine and fishery development. Based on the background and the above problem formulation, the purposes of this research are as follows: (1) analyzing the constraints of DAK KP distribution; (2) analyzing the impact of DAK KP distribution; and (3) formulating the strategies required to improve the effectiveness of DAK KP distribution.

The method used to formulate a strategy is a SWOT analysis. SWOT analysis is often used for research methods. Anggraeni et al. (2014) in her journal examined the internal and external factors of optimal and sustainable fisheries resources management in Pulau Panjang waters of Serang Regency of Banten Province. The methods used were analyses of EFE and IFE as well as of SWOT matrix to get alternative strategies. Based on the research result, the best strategy is strategy of diversification. This strategy can be conducted using the power to overcome the threats. Malotes (2016) in his journal examined the strategy of business development of beef cattle in North Tinangkung District Banggai Kepulauan Regency. The methods used were EFE and IFE analyses and SWOT matrix to obtain alternative strategies. Based on the result of the research, it is found that the best strategy to be implemented is SO strategy, that is meeting between opportunities from outside with the strength of North Tinangkung District. Almutahar et al. (2013) in his journal examined the strategy analysis of Sungau Rengas coastal fishery in Kubu Raya-West Kalimantan. The analysis methods used were SWOT matrix followed by QSPM analysis. The results show 5 strategies that have appeal to be implemented, among others: (1) improvement in fisheries production, (2) market segmentation, (3) control in the sale of PPP
River Rengas fish, (4) business development in harbor environment, and (5) increase and stabilization of fuel supply.

The scope of this research is to discuss the distribution of Special Allocation Fund of Marine and Fishery Field using Regression Data Panel analysis to know the effects of variables used on the production of capture fishery and aquaculture and using Analysis of Strengths - Weakness - Opportunities - Threats (SWOT) to find out the required strategy to improve the effectiveness of DAK KP distribution.

\section{METHODS}

The research was conducted at the Ministry National Planning and Development (Bappenas). The time of the research was from October 2017 to February 2018. The populations used in the panel regression analysis of this study included all regions that obtained DAK KP allocation from 2012 to 2015. The populations came from 32 provinces, while provinces that were not included in the population were those (provinces or regencies/municipalities) that did not obtain DAK KP allocation from 2012 to 2015 (DKI Jakarta and North Kalimantan). The variables that used for panel data regression analysis in Table 1.

The method of analysis of strategy formulation was carried out by distributing questionnaires and interviews with experts in DAK field, especially in marine and fishery field which is divided into 3 stages. The experts were from the Bappenas, Ministry of Marine and Fisheries Affairs (KKP), Ministry of Finance (Kemenkeu), Ministry of Internal Affairs (Kemendagri), academics, and local government. Samples drawn from Bappenas, KKP, Kemenkeu, Kemendagri, and academics were selected by Expert Sampling method i.e. sampling method based on expertise. Sampling for local government was conducted using Convenience Sampling Method.

The following is a model of this study that will look at the effects of independent variables from capture fisheries (DAK, APBN, fishing vessels, fishing gear, and fishermen) and aquaculture fisheries (DAK, APBN, seeds, fish farmer, and fish farming area) on the dependent variable of fishery production. Fishery production is one outcome of the distribution of DAK KP. The result of regression analysis of panel data 
was used as the basis to find out whether the DAK KP distribution has had an impact to increase fishery production. The models of panel data regression used were an adopted model from (Zebua and Ramli, 2013). The models of panel data regression designed in this study are as follows:

\section{Capture fisheries:}

$\mathrm{Y}_{\mathrm{it}}=\alpha_{0}+\alpha_{1} \mathrm{DAK}_{\mathrm{it}}+\alpha_{2} \mathrm{APBN}_{\mathrm{it}}+\alpha_{3} \mathrm{~K}_{\mathrm{it}}+\alpha_{4} \mathrm{API}_{\mathrm{it}}+\alpha_{5} \mathrm{~N}_{\mathrm{it}}+\mathrm{e}_{\mathrm{it}}$

$\mathrm{Y}_{\mathrm{it}}$ (Capture Fisheries Production (ton)); $\alpha_{0}$ (Intercept (constants)); DAK $_{\text {it }}$ (DAK KP allocation (Rp)); APBNit (APBN allocation (Rp)); $\mathrm{K}_{\text {it }}$ (Fishing Vessels (units)); API $_{\text {it }}$ (Fishing Gear (units)); $\mathrm{N}_{\text {it }}$ (Fisherman (person)); $\mathrm{e}_{\mathrm{it}}$ (Standard error (Error term)); i (Province $\left.\left(i_{1}, i_{2}, i_{3}, \ldots i_{32}\right)\right) ; t_{t}\left(\right.$ Time $\left.\left(t_{1}, t_{2}, t_{3}, t_{4}\right)\right)$.

Aquaculture Fisheries:

$\mathrm{Y}_{\mathrm{it}}=\alpha_{0}+\alpha_{1} \mathrm{DAK}_{\mathrm{it}}+\alpha_{2} \mathrm{APBN}_{\mathrm{it}}+\alpha_{3} \mathrm{~K}_{\mathrm{it}}+\alpha_{4} \mathrm{UPI}_{\mathrm{it}}+\alpha_{5} \mathrm{~N}_{\mathrm{it}}+\mathrm{e}_{\mathrm{it}}$
$\mathrm{Y}_{\text {it }}$ (Aquaculture Fisheries Production (ton)); $\alpha_{0}$ (Intercept (constants)); $\mathrm{DAK}_{\mathrm{it}}$ (DAK KP allocation $(\mathrm{Rp})) ; \mathrm{APBN}_{\mathrm{it}}\left(\mathrm{APBN}\right.$ allocation (Rp)); $\mathrm{B}_{\mathrm{it}}$ (Fish Seed (seed)); $\mathrm{P}_{\mathrm{it}}$ (Fish Farmer (person)); $\mathrm{L}_{\mathrm{it}}$ (Fish Farming Area (ha)); $\mathrm{e}_{\mathrm{it}}$ (Standard error (Error term)); i (Province $\left.\left(\mathrm{i}_{1}, \mathrm{i}_{2}, \mathrm{i}_{3}, \ldots \mathrm{i}_{32}\right)\right) ; \mathrm{t}_{\mathrm{t}}\left(\right.$ Time $\left.\left(\mathrm{t}_{1}, \mathrm{t}_{2}, \mathrm{t}_{3}, \mathrm{t}_{4}\right)\right)$.

The study was initiated by the huge opportunities for Indonesia to utilize and develop the fisheries potentials optimally, and the central government through the Special Allocation Fund for Marine and Fishery (DAK $\mathrm{KP}$ ) provides funds the physical development activities in the field of marine and fisheries; however, there are still many obstacles in the implementation process of DAK KP. The preliminary analysis of the research used panel data to determine the effects of capture fishery production and aquaculture production on some independent variables as shown in Figure 1. Further analysis using Internal Factor Evaluation and External Factor Evaluation was followed by SWOT Matrix to formulate the best strategy to be implemented.

Table 1. Variable data panel

Variables Definition

Capture fishery production the result of catching or collected fish/other aquatic animals/ aquatic plants that live in the sea/public waters freely and do not live individually (ton) (BPS, 2017)

Production of aquaculture The result of activities of raising fish/other aquatic animals/ aquatic plants using artificial facilities (ton) (BPS, 2017)

DAK capture fishery/ DAK KP allocation related to capture fishery/aquaculture activity (Rp)

aquaculture

APBN capture fishery/ aquaculture

Fishing vessels

Fishing gear

Fishermen

Seed

Fish farmer

Fish farming area
Marine and fisheries budget (APBN) allocation related to capture fishery/aquaculture activities (Rp). The calculated APBN allocation is the Deconcentration and CoAdministration Fund. Deconcentration funds in marine and fishery fields will be funds derived from the budget of the Ministry of Marine and Fisheries Affairs conducted by the Governor as the representative of the central government which includes all revenues and expenditures in the implementation of deconcentration in the field of marine and fisheries. Co-administered Task Force on Marine and Fishery Affairs will be funds derived from the budget of the Ministry of Marine Affairs and Fisheries carried out by the provincial and/or district/municipal governments covering all revenues and expenditures in the implementation of assistance tasks in the field of marine and fisheries.

Vessels directly used in other fishing operations/aquatic animals/ aquatic plants (units) (BPS, 2017)

The equipment that fishermen use to catch fish and other marine animals (units) (Lisdawati et al. 2016)

A community that live in coastal areas with main livelihood is to manage and utilize natural resources contained in coastal and marine waters, whether in the form of fish, shrimp, sea grass coral reefs or other marine biota (person) (Arnawa et al. 2016)

The phase after the larvae, and they are usually ready to stock in the enlargement pond Residents conducting aquaculture activities (persons)

The water surface area used for all aquaculture activities (Ha) (BPS, 2017) 


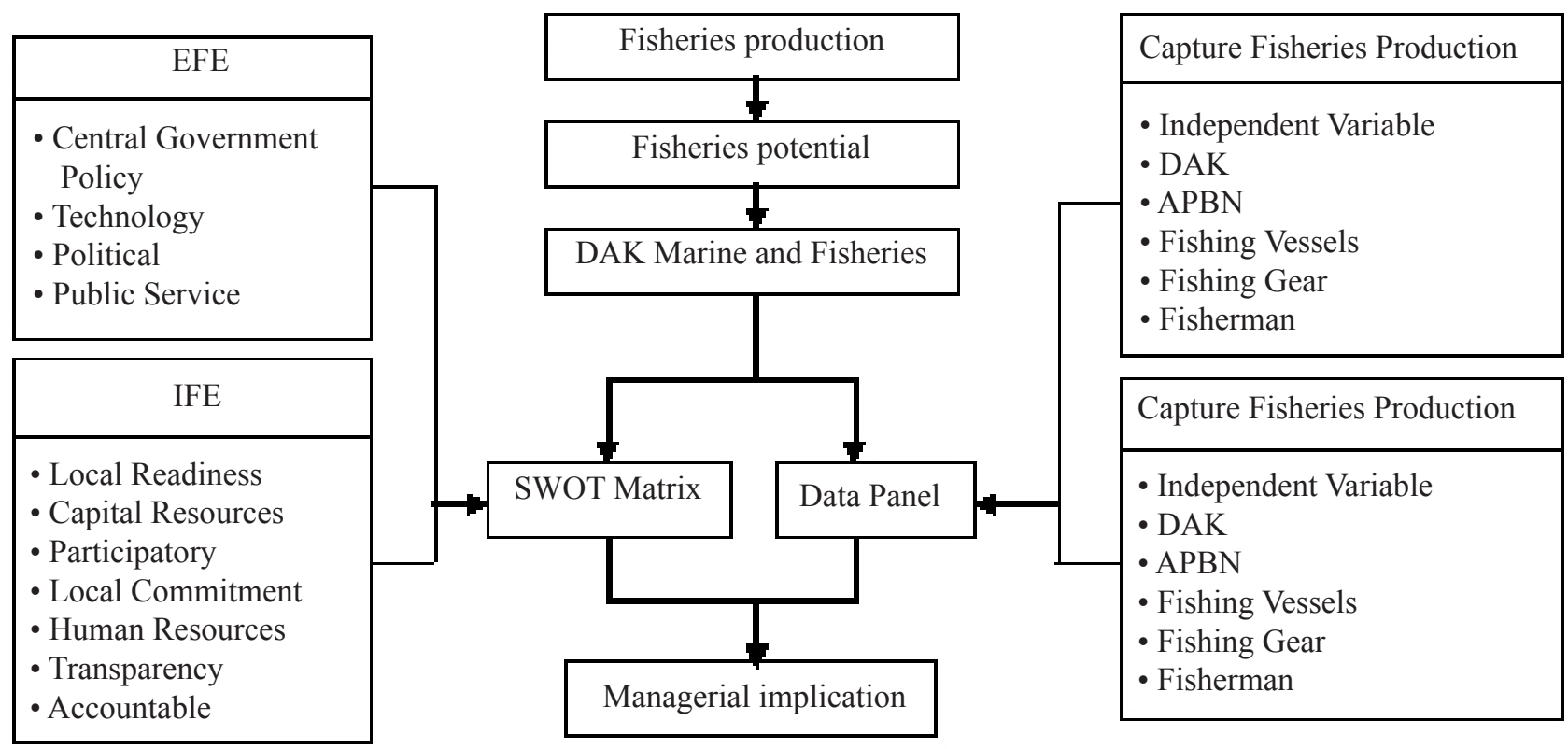

Figure. 1. Research framework

The study analyzed the main factors affecting fishery production, one of which was DAK KP. The hypothesis for panel regression analysis of this study is as follows:

\section{Capture fisheries:}

H1 : The amount of DAK fishery allocation has an influence on the production of capture fisheries

H2 : The amount of APBN allocations has an influence on the production of capture fisheries

H3 : Thenumber of fishing vessels has an influence on the production of capture fisheries

H4 : The number of fishing gear has an influence on the production of capture fisheries

H5 : The number of fishermen has an influence on the production of capture fisheries

Aquaculture fisheries:

H6 : The amount of DAK allocation of aquaculture fishery has an influence on the production of aquaculture fishery

H7 : The amount of APBN allocation has an influence on the production of aquaculture fishery

H8 : The number of fish seeds has an influence on the production of aquaculture fishery

H9 : The number of fish farmer has an influence on the production of aquaculture fishery

H10 : The area of fish farming area has an influence on the production of aquaculture fishery

\section{RESULT}

\section{Results of Regression of Fishery Variables on Production}

The panel data regression analysis was performed using 3 models, including: Ordinary Least Square (OLS), Fixed Effect Model (FEM), and Random Effect Model (REM). To determine the model used between OLS or FEM, Chow Test or likehood ratio test was used, whereas to determine the model between FEM or REM, Hausman Test was used. The research used Eviews 9 software to analyze the regression model. The result of Chow Test or likehood ratio test performed in this research (Table 2). Based on the results of Chow Test on all models, they showed that Fixed Effect Model is better than Ordinary Least Square as it can be seen from Prob. value of $0.000<$ alpha $5 \%$. The result of Hasuman Test conducted in this research (Table 3 ).

Based on the results of Chow Test on all models (Table 3), it is shown that Fixed Effect Model is better than Random Effect Model as it is seen from Prob. value 0.0066 and Prob. $0.0017<$ alpha 5\%. Referring to the result of Chow Test and Hausman Test, it can be concluded that the best model used is Fixed Effect Model. The result is in accordance with the statement of Silalahi et al. (2014) stating that if the cross section is larger than the time series, it is then better to use FEM. 
After determining the model, it is necessary to test the classical assumption of the regression model selected and the fixed effect model to determine the results of the regression model that it does not cointain a classical assumption, including: normality, heteroscedasticity, autocorrelation and multicollinearity. This classical assumption test was performed to obtain a BLUE (Best Linear Unbiased Estimator) model (Rizki, 2016). In this study, generalized least square (GLS) was used to overcome the problem of classical assumptions on the regression model. The results of classical assumption test on both parameters (capture fishery and aquaculture fishery) are as follows:

1. Normality test aims to measure whether the data obtained follow the normal distribution or not (Kurniawan et al. 2015). Normality test results on the capture and aquaculture model show a JarqueBera probability value greater than 0.05 . The probability values of Jarque-Bera capture fishery and aquaculture are 0.089 and 0.169 respectively, so the model has fulfilled the assumption of normality.

2. Heteroscedasticity test aims to test the inequality of variance between observations (Kurniawan et al. 2015). The results of heteroscedasticity test on both capture and cultivation fishery parameters showed no heteroscedasticities which can be seen from standardized residuals which do not form a pattern.

3. Autocorrelation test is defined as the correlation between members in a series of observations that are sorted by time series or cross-section (Kurniawan et al. 2015). The result of autocorrelation test showed that Durbin Watson values on both parameters showed no positive autocorrelations or negative autocorrelations with $\mathrm{d}$ values of capture fishery and aquaculture are 1.991402 and 1.606394 respectively (Tables 4 and 5), while Durbin Watson table value with $\alpha 1 \%$ intercept is $\mathrm{dL}=0.917$ and $\mathrm{dU}=1.597$.

4. Multicolinearity testaims to see the linear relationship among the independent variables (Kurniawan et al. 2015). The results of multicolinearity test on both parameters of capture fishery and aquaculture showed no correlation values among the variables greater than 0.8 , and this shows that there is no problem of multicollinearity in the regression model.

After there is no problem of classical assumptions on the regression model, the regression model can be used for further analysis. The following is the result of fixed effect regression model with weighting cross section weights (GLS) presented in Table 4 and Table 5.

Table 2. Chow test

\begin{tabular}{lccccc}
\hline \multicolumn{1}{c}{ Model } & Effects Test & Statistic & d.f. & Prob. & Conclusion \\
\hline Capture Fisheries & Cross-section F & 90.073850 & $(31,91)$ & 0.0000 & FEM \\
Aquaculture Fisheries & Cross-section F & 88.058448 & $(31,91)$ & 0.0000 & FEM \\
\hline
\end{tabular}

Table 3. Hausman test

\begin{tabular}{lccccc}
\hline \multicolumn{1}{c}{ Model } & Test Summary & Chi-Sq. Statistic & Chi-Sq. d.f. & Prob. & Conclusion \\
\hline Capture Fisheries & Cross-section random & 16.077892 & 5 & 0.0066 & FEM \\
Aquaculture Fisheries & Cross-section random & 19.262103 & 5 & 0.0017 & FEM \\
\hline
\end{tabular}

Table 4. Influence of capture fisheries variable to capture fisheries production

\begin{tabular}{lll}
\hline \multicolumn{1}{c}{ Variable } & Coefficient & \multicolumn{1}{c}{ Significance } \\
\hline DAK KP & $-1.78 \mathrm{E}-07$ & Not Significant \\
APBN & $2.25 \mathrm{E}-07$ & Significant at $\alpha$ 5 $\%$ \\
$\mathrm{~K}$ & 1.153433 & Significant at $\alpha$ 5\% \\
API & 0.122317 & Significant at $\alpha 10 \%$ \\
N & 0.146914 & Significant at $\alpha 10 \%$ \\
R-squared & 0.992494 & \\
Adjusted R-square & 0.989524 & \\
F-statistic & 334.2353 & \\
Prob. (F-statistic) & 0.000000 & \\
Durbin Watson stat & 1.991402 & \\
\hline
\end{tabular}


Table 5. Influence of aquaculture fisheries variable on aquaculture fisheries production

\begin{tabular}{lcl}
\hline \multicolumn{1}{c}{ Variable } & Coefficient & \multicolumn{1}{c}{ Significance } \\
\hline DAK KP & $2.14 \mathrm{E}-06$ & Significant at $\alpha 1 \%$ \\
APBN & $-1.87 \mathrm{E}-05$ & Significant at $\alpha 1 \%$ \\
B & -0.868644 & Significant at $\alpha$ 5\% \\
P & -0.114866 & Not Significant \\
L & 0.026801 & Significant at $\alpha 1 \%$ \\
\hline R-squared & 0.995840 & \\
Adjusted R-square & 0.994194 & \\
F-statistic & 605.0798 & \\
Prob. (F-statistic) & 0.000000 & \\
Durbin Watson stat & 1.606394 & \\
\hline
\end{tabular}

Based on Table 4, the value of R-squared is 0.992494 . This shows the diversity of DAK, APBN, Fishing Vessels, Fishing Gear, and Fisherman variables can explain the diversity of capture fisheries production of $99.25 \%$ while the rest is explained by other factors not included in the research model, and $\mathrm{F}$ test results show that $\mathrm{p}$-value $\mathrm{F}$ statistic is smaller than alpha $5 \%$, so $\mathrm{H} 0$ is rejected or $\mathrm{H} 1$ is accepted, meaning that there is at least one of the variables of DAK, APBN, Fishing Vessels, Fishing Gear, and Fisherman affects the production of capture fisheries.

Based on Table 5, the value of R-squared is 0.995840 . This shows the diversity of DAK, APBN, Fish Seed, Fish Farmer, and Fish Farming Area variables can explain the diversity of aquaculture fisheries production of $99.58 \%$ while the rest is explained by other factors not included in the research model. $F$ test results show that $p$-value of F statistics is smaller than alpha $5 \%$, so $\mathrm{H} 0$ is rejected or $\mathrm{H} 1$ is accepted, meaning that there is at least one of the variables of DAK, APBN, Fish Seed, Fish Farmer, and Fish Farming Area affects the production of aquaculture fisheries.

Based on Table 4 and Table 5, DAK Capture Fisheries variables have no significant effects on Capture Fisheries Production, while DAK Aquaculture Fisheries variables have significant effects on Aquaculture Fisheries Production. The distribution of DAK KP should increase fishery production. This is in line with the objective of the DAK KP allocation, which is to improve the basic infrastructure in the field of marine and fisheries, especially in supporting the development and cultivation of fisheries and development of small islands in the region (Sujadmiko, 2011). Based on the result of her study, Muharni (2008) stated that special allocation fund has a positive and significant influence on the economic growth of regency/city in Riau Province.
Based on the results of the research, Sujadmiko (2011) stated that the allocation of DAK allocations to regions is still very small, so it is recommended that the central government need to allocate larger DAK allocation, because in addition to the largest area in the region, the region also needs acceleration of development. In addition to the minimal allocation of DAK KP, the realization of DAK activities is also very influential on the development of marine and fishery fields. In addition, the realization of DAK KP is still quite effective. If the realization of physical development is not met, then the utilization of the infrastructure development will also be felt less beneficial. Based on the results of the BPK audit report in the second half of 2015, it stated that the Special Allocation Fund (DAK) budget in APBN/P of 2014 to 2015 and APBN of 2016 is not yet fully effective to support the implementation of RKP 2014 to 2016.

\section{Impact of Distribution of DAK KP}

Aquaculture fishery activities of community empowerment in Pangkajene Kepulauan Regency

In 2014, a seeding pond of biofloc system for catfish, goldfish, and tilapia commodities was built by Santarie Group consisting of 10 people in Bontomatene Village, Segeri Sub-district. The production of catfishes previously reached 50,000 seeds/week, but it now can reach 70,000 seeds/week after receiving grants for the pond construction from the soil to cement.

Aquaculture fishery activities in Jambi Province

The activities of DAK KP in UPTD-BBID Telanaipura Jambi include the rehabilitations of: (1) 6 major ponds, (2) channels, (3) hatchery building, (4) reservoir, and (5) water tank. The target achievement of UPTD- 
BBID Telanaipura Jambi is 60 million rupiahs per year, realization of 62 million rupiahs per year. DAK KP activities in UPTD BBI Simpang Rimbo Jambi in 2016 were the rehabilitation of 8 ponds and the hatchery development in 2017. The target achievement of UPTD BBI Simpang Rimbo amounted to 100 million rupiahs per year, so the realization has exceeded the target.

\section{Strategy Formulation Analysis}

\section{Internal Factor Evaluation (IFE) Analysis}

The IFE matrix analysis is the result of the identification of internal factors affecting the distribution of DAK KP in the local government scope, and it was then weighted, as shown in Table 6. The total score for internal factors is 1.9377. David (2016) states that the value of internal factors below 2.5 illustrates that the firm is internally weak.

\section{External Factor Evaluation (EFE) Analysis}

The EFE matrix analysis is the result of identification of external factors influencing the distribution of DAK $\mathrm{KP}$ in the local government scope as shown in Table 7. Total score for external factors is 3.3394. Based on this value, it means that local governments have good responses to the opportunities that exist and avoid threats (David, 2016).

Table 6. Matrix IFE Analysis

\section{Internal Factor}

Average
Weight Rating Score

\section{Weaknesses}

Lack of the control from the ranks of local governments over the process of DAK KP activities

Lack of coordination ability between the local government districts/city and the province

Lack of ability to overcome the problems that occur in the field

Lack of availability of operational costs to support DAK KP activities

Lack of discipline in submitting periodic progress reports of DAK KP

The proposal of DAK KP does not match the menu provided

The area is inconsistent and changes the menu selected during the activities on progress

Officials/executors associated with DAK KP perform tasks not fully based on the applicable rule guidelines (technical guidance)

No clearance for land to build marine and fisheries infrastructure

The absence of planning documents for the development of marine and fisheries infrastructure (such as Master plan or Detailed Engineering Design) by local governments

Delay in contract process with the third party (tender)

\begin{tabular}{|c|c|c|c|}
\hline Delay in contract process with the third party (tender) & 0.0671 & 1.1 & 0.0738 \\
\hline Sub-total & 0.6907 & & 1.0232 \\
\hline \multicolumn{4}{|l|}{ Strengths } \\
\hline Local government financial management capability & 0.0412 & 2.7 & 0.1111 \\
\hline Sufficient number of fishermen and fish farmers & 0.0359 & 2.8 & 0.0998 \\
\hline Sufficient number of human resources in the scope of local government & 0.0419 & 3.2 & 0.1342 \\
\hline $\begin{array}{l}\text { Relevant officials/executors in the performance of duties are not willing to accept non- } \\
\text { regulation/rewards }\end{array}$ & 0.0496 & 2.8 & 0.1390 \\
\hline $\begin{array}{l}\text { Transparency of DAK KP report from each government/ unit level in the implementation } \\
\text { process }\end{array}$ & 0.0518 & 2.9 & 0.1502 \\
\hline All parties are involved in the process of DAK KP activities & 0.0417 & 3.1 & 0.1291 \\
\hline Overall results of the DAK KP utilization process are accountable & 0.0472 & 3.2 & 0.1510 \\
\hline Sub Total & 0.3093 & & 0.9145 \\
\hline Total & 1 & & 1.9377 \\
\hline
\end{tabular}

\begin{tabular}{lll}
0.0621 & 1.5 & 0.0931 \\
0.0679 & 1.3 & 0.0883 \\
0.0474 & 2.0 & 0.0948 \\
0.0652 & 1.6 & 0.1043 \\
0.0670 & 1.3 & 0.0871 \\
0.0639 & 1.3 & 0.0851 \\
0.0590 & 1.5 & 0.0885 \\
0.0575 & 2.0 & 0.1150 \\
0.0648 & 1.6 & 0.1037 \\
0.0689 & 1.3 & 0.0896 \\
0.0671 & 1.1 & 0.0738 \\
\hline 0.6907 & & 1.0232
\end{tabular}

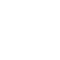




\begin{tabular}{|c|c|c|c|}
\hline External Factor & $\begin{array}{l}\text { Average } \\
\text { Weight }\end{array}$ & Rating & Score \\
\hline \multicolumn{4}{|l|}{ Threats } \\
\hline The existence of policies/rules regarding the requirements of DAK KP recipients & 0.0669 & 3.3 & 0.2207 \\
\hline The menu provided by the central government is less appropriate to the needs of the region & 0.0701 & 3.4 & 0.2384 \\
\hline Delayed disbursement of DAK KP & 0.0663 & 3.3 & 0.2188 \\
\hline Minimum DAK KP allocation & 0.0609 & 3.3 & 0.2010 \\
\hline Unfavorable political situation has an impact on local government & 0.0599 & 3.1 & 0.1856 \\
\hline Change of work cabinet in the scope of local government & 0.0716 & 3.7 & 0.2651 \\
\hline Rules/Policies related to zoning plans & 0.0593 & 3.3 & 0.1955 \\
\hline Sub-total & 0.4550 & & 1.5251 \\
\hline \multicolumn{4}{|l|}{ Opportunities } \\
\hline The proposed DAK KP process can be conducted easily & 0.0695 & 3.4 & 0.2362 \\
\hline DAK KP information and provisions can be accessed online & 0.0704 & 3.6 & 0.2536 \\
\hline DAK KP activities can be reported online by the local government & 0.0622 & 3.5 & 0.2177 \\
\hline $\begin{array}{l}\text { DAK KP activities, menu, and procedures for proposing DAK KP are socialized to the } \\
\text { regions }\end{array}$ & 0.0742 & 3.6 & 0.2670 \\
\hline Increasing the number of human resources in DAK KP at the central level & 0.0434 & 2.8 & 0.1216 \\
\hline Regions may consult directly with the central government & 0.0744 & 3.5 & 0.2603 \\
\hline Central government meets the aspect of justice and is not discriminatory & 0.0510 & 3.1 & 0.1581 \\
\hline $\begin{array}{l}\text { Determination of the amount of DAK KP allocation will be based on certain criteria } \\
\text { established by the central government }\end{array}$ & 0.0529 & 3 & 0.1586 \\
\hline $\begin{array}{l}\text { Amount of allocation per region is submitted by the central government through the } \\
\text { applicable regulations }\end{array}$ & 0.0471 & 3 & 0.1413 \\
\hline Sub-total & 0.5450 & & 1.8143 \\
\hline Total & 1 & & 3.3394 \\
\hline
\end{tabular}

Formulation of Alternative Strategies Using SWOT Matrix

SWOT matrix analysis in the research was conducted to improve the analysis that had been done on IFE and EFE matrix analyses. IFE matrix results in total score for strengths and weaknesses factors and EFE matrix results in total score for threats and opportunities. Differences in total scores of strengths and weaknesses and threats and opportunities were mapped into SWOT matrix diagrams. The total scores of strengths and weaknesses were mapped on $\mathrm{x}$-axis, while the total scores of opportunities and threats were mapped on the $\mathrm{y}$-axis. It can then be determined in the quadrant where local government positions are located and on which alternative strategies should be undertaken. Strategies are often defined as an adjustment by an organization between its resources and internal skills as well as the opportunities and risks created by external factors (Segoro and Rizal, 2017). Based on the calculation, the total score for the strength factor was 0.9145 and total score for the weakness factor was 1.0232 and total score for the probability factor was 1.8143 and the total score for the threat factor was 1.5251 . The difference between strengths and weaknesses was (-) 0.1087, while that of opportunities and threats was $(+) 0.2892$. Overview of the mapping result of total matrixes of internal and external factors in the SWOT matrix diagram (Figure 2).

Based on Figure 2, it appears that the best strategy to be implemented by the local government is a turnaround strategy. Syafrizal (2006) stated that the turnaround strategy, is a strategy to restore the company's condition from a downturn/crisis to a healthier and better company (turn around). Turn around is a reversal of the company's direction of performance degradation. A successful turn-around is a complex process involving a combination of environmental factors, internal resources, relevant company strategies at different stages of performance degradation, resulting in improved financial performance. The company requires an effective strategy to achieve recovery or success of turn-around (Lestari and Triani, 2013). 
The focus of this company's strategy is to minimize the company's internal problems so as to seize more market opportunities (Sari, 2017). The focuses of turnround strategy are minimizing the internal company problems and then reclaim better markets and focusing on strategies in order to take advantage of market opportunities and minimize internal weaknesses of the company (Amalia, 2016) or WO (Weakness -Opportunities) strategy. The WO strategy matrix in Table 8.

\section{Managerial Implications}

Based on the SWOT matrix analysis, the applicable managerial implications for the Central Government are as follows: Establishing more effective and efficient coordination, synchronization and harmonization forums so that the regions can fully understand the process of DAK KP activities and their proposing procedures and convey information related to menu of activities, timeline, proposing procedures, and other matters through social media, electronics, as well as correspondence to the local government. The central government also needs to hold an evaluation forum between the central and regional levels at the end of the current year in order to accommodate all of the arising problems in the field and accommodate the regional aspirations regarding the required menu by the region as input in the following year. The central government will accommodate and sort out proposals from local governments and determine which menu that the majority of the regions need, and the government adjusts those menus with National Priorities.

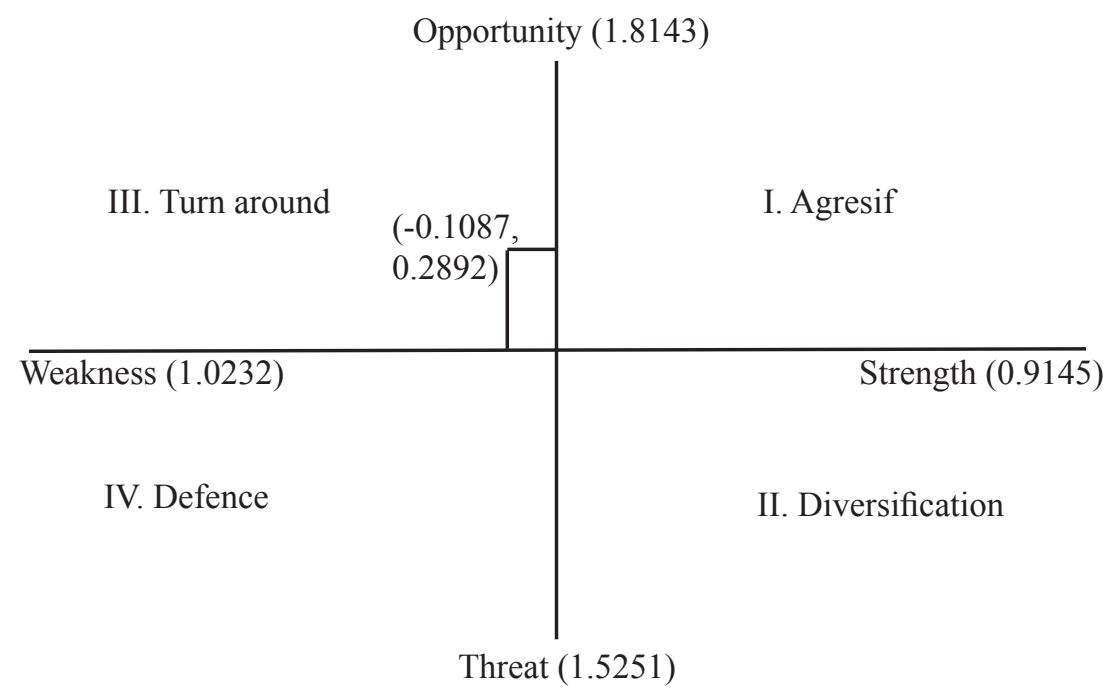

Figure 2. SWOT Matrix Diagram

Table 8. Formulation of SWOT matrix strategy combination

The central government increases the effectiveness of socialization activities and expands the
intensity of communication with local governments
Conducting an extension program on the benefits of DAK KP, training, and skill development to
OPPORTUNITIES $(\mathrm{O}) \quad \begin{aligned} & \text { Wotential beneficiaries } \\ & \text { There is an availability of integrated applications between the central government and local } \\ & \text { governments } \\ & \text { There is also an existing assistance of all process of regional DAK KP activity }\end{aligned}$


Modifying or expanding program/ menu/existing menu items appropriate to regional needs and can be used by the majority of beneficiaries. For example, the provision of fishing gear/vessel must be adapted to the waters condition in the area and fishing gear is also multifunctional that it can be used by various types of vessels. The expansion of menu details is intended to allow the regions to complement the needs of facilities and infrastructure that are not yet available in the regions to support maximizing output. In the selection of menu details, it can be adjusted to the factors that affect the production of fisheries to actualize Government Work Plan (RKP) targets.

Creating integrated DAK applications by the Central Government, and the applications should be accessible to central and local governments, easy to apply and multifunctional. Multifunctional is intended for applications not only to be used for proposal submission, but can also be used for reporting and consultation. The supervision of the entire process of DAK KP activities in the regions is also indispensable in the planning and monitoring process. Regional readiness is greatly important to fulfill during the planning process in order to expect no obstacles during implementation process. Monitoring is intended to anticipate any problems in the field or the emerging deviations during the DAK implementation process.

Based on the SWOT matrix analysis, the applicable managerial implications for the local government include: (1) Conducting counseling on the benefits of DAK KP to prospective recipients so the potential recipients understand the activities of DAK KP and its programs better. Increased training and skill development of potential recipients are also required to actualize the program and optimize the utilization of DAK KP activities. (2) Providing assistance to all process of DAK KP activity is also greatly necessary especially to the regional marine and fishery department. It conducts monitoring to identify the development or progress of DAK KP activities and the occurring problems in the field during the process of DAK implementation activities.

\section{CONCLUSIONS AND RECOMMENDATIONS}

\section{Conclusions}

Based on the results of the analysis conducted, it can be concluded: (1) DAK KP variable has no significant effects on capture fisheries production but has significant effects on aquaculture fisheries production. This indicates that the allocation of DAK KP still has not provided an outcome in line with the expectation to increase fishery production, thus proving that there are still constraints in the distribution of DAK KP, especially in capture fisheries; (2) The main constraint of DAK KP distribution based on the result of the weighting of the internal factor matrix is the regional readiness factor; while based on the weighting of the matrix of external factors, it is a political factor; (3) The result of strategy formulation analysis with SWOT matrix represents that the local government is in quadrant III. Recommended strategy alternatives are to increase the effectiveness of socialization activities and expand the intensity of communication with the local government; to conduct a counseling program on the benefits of DAK KP, training, and skill development to potential beneficiaries; and to create integrated applications between the central and local governments; and to assist the entire process of regional DAK KP activities.

\section{Recommendations}

Based on the results of the research and conclusions put forward, suggestions based on the results of the analysis conducted are as follows: (1) the local governments are expected to improve the realization of DAK KP disbursement by overcoming weaknesses and taking advantage of opportunities; (2) the central government is expected to provide policies that support the region in order to accelerate the distribution of DAK KP; dan (3) further research can analyze the distribution strategy of DAK for other fields.

\section{REFERENCES}

Aimon H, Putra RL. 2016. Analisis pendapatan asli daerah dan dana perimbangan terhadap pertumbuhan ekonomi kabupaten kota di Sumatera Barat. Jurnal Kajian Ekonomi 4(7):116. 
Almutahar AM, Sutjipto DO, Sukandar. 2013. Analisis strategi pengelolaan pelabuhan perikanan pantai sungai rengas Kabupaten Kubu Raya-Kalimantan Barat. PSPK Student Journal 1(1):1-10.

AmaliaA.2016. Perencanaan strategi pemasaran dengan pendekatan bauran pemasaran dan SWOT pada perusahaan popsy tubby. Jurnal Manajemen dan Start-Up Bisnis 1(3):297-306.

Anggraeni D, Aliudin, Haryati S. 2014. Faktor internal dan ekstrnal pengelolaan sumberdaya perikanan secara optimal dan berkelanjutan di perairan Pulau Panjang Kabupaten Serang Provinsi Banten. Jurnal Ilmu Pertanian dan Perikanan 3(1):19-29.

Bangun RAL. 2009. Pengaruh dana alokasi khusus, dana alokasi umum, dan pendapatan asli daerah terhadap pendapatan perkapita [thesis]. Medan: Universitas Sumatera Utara.

[BPS] Badan Pusat Statistik. 2017. Produk domestik bruto (lapangan usaha). https://www.bps.go.id/ Subjek/view/id/11\#subjekViewTab3|accordiondaftar-subjek2. [10 February 2017].

David EM, David FR, David FR. 2016. The quantitative strategic planning matrix: a new marketing tool. Journal of Strategic Marketing 25(4):342-352. https://doi.org/10.1080/0965254X.2016.114876 3.

Hudjuala W. 2017. Efektivitas pemanfaatan alokasi dana desa dalam menunjang pembangunan. http:// www.academia.edu/15102707/EFEKTIVITAS PEMANFAATAN_ALOKASI_DANA_DESA_ DALAM_MENUNJANG_PEMBANGUNAN. [12 April 2017]

Kurniawan AE, Herrhyanto N, Agustina F. 2015. Model regresi data panel berganda (contoh kasus: data hubungan valuasi (cum dividen price (CDP) yang diduga dipengaruhi oleh laba (earnings per share (EPS)) dan nilai buku ekuitas (book value (BV)) pada tahun 1991-2000). Jurnal EureMatika 3(1):42-58.

Lestari RD, TrianiNNA. 2013. Determinan keberhasilan turnaround pada perusahaan yang mengalami financial distress. Jurnal Ilmu Manajemen 1(4):1142-1154.

Lisdawati A, Najamuddin, Assir A. 2016. Deskripsi alat tangkap ikan di Kecamatan Bontomanai Kabupaten Kepulauan Selayar. Jurnal IPTEKS PSP 3(6):553-571.
Malotes J. 2016. Strategi pengembangan usaha peternakan sapi potong di Kecamatan Tinangkung Utara Kabupaten Banggai Kepulauan. Jurnal Agroland 23(3):198-207.

Muharni. 2008. Pengaruh Belanja Modal, Dana Akokasi Khusus, dan Investasi Swasta terhadap Pertumbuhan Ekonomi Studi pada Kabupaten atau Kota di Provinsi Riau [thesis]. Yogyakarta: Universitas Gajah Mada.

Novarianti N. 2016. Pengaruh pendapatan asli daerah, dana alokasi umum, dan dana alokasi khusus terhadap indeks pembangunan manusia dengan belanja modal sebagai variabel pemediasi pada kabupaten/kota di Indonesia 2010-2013 [thesis]. Bandar Lampung: Universitas Lampung.

Sari AK. 2017. Analisis strategi pemasaran dalam upaya meningkatkan penjualan pada perusahaan telkomsel distribution center bojonegoro. Jurnal Ilmu Sosial dan Humaniora 5(1):1-26.

Sari R. 2014. Dampak kebijakan desentralisasi fiskal pada daerah tertinggal di Indonesia. Jurnal Ekonomi dan Kebijakan Publik 5(1):79-99.

Segoro W, Rizal R. 2017. The competitive strategy for a shari'a business unit (SBU): pension fund management from PT Bank Muamalat Indonesia. International Journal of Economic Research 14(5):125-132.

SilalahiD, Sitepu R, Tarigan G. 2014. Analisis ketahanan pangan provinsi sumatera utara dengan metode regresi data panel. Jurnal Saintia Matematika 2(3):237-251.

Suhendra IMDS, Sulindawati NLGE, Adiputra IMP. 2015. Pengaruh dana alokasi umum (DAU), dana alokasi khusus (DAK), dan belanja pemeliharaan terhadap pengalokasian anggaran belanja modal pada kabupaten/kota di Bali Periode 20092013. e-Journal S1 Ak Universitas Pendidikan Ganesha 3(1):1-11.

Sujadmiko G. 2011. Pengaturan Dana Alokasi Khusus Dalam Hubungan Keuangan Pusat dan Daerah. [thesis]. Denpasar: Universitas Udayana.

Syafrizal. 2006. Analisis strategi turnaround pada perusahaan yang terdaftar di bursa efek Jakarta. Jurnal Business \& Manajemen 2(1):1-8.

Zebua ND, Ramli. 2013. Analisis pengaruh jumlah armada, jumlah nelayan, PDRB, dan investasi terhadap produksi perikanan di wilayah Nias. Jurnal Ekonomi dan Keuangan 2(8):463-474. 